2. Левон Ф. М., Кузнецов С. І.Концептуальні аспекти формування міських зелених насаджень у сучасних умовах // Інтродукція рослин, 2006. - С. 53-57.

3. Зенькович Н. Г. Особливості формування дизайну міського середовища // Архітектурний вісник КНУБА, 2014. - № 4. - С. 149-155.

4. Бат Н. Типологія ландшафтного дизайну в міському середовищі // Мистецтвознавчі записки, 2010. - № 18. - С. 312-319.

5. Бриджуотер А. и Д. Ландшафтный дизайн.- Харьков-Белгород, 2010. - 112 с.

6. Белочкина Ю. Ландшафтный дизайн. - Харьков: Фолио, 2006. - 317 с.

7. Ковальський Л. Н. Архитектура учебно-воспитательных зданий. - К.: Будивельник, 1983. - 143 с.

8. Лихачев Д. С. Поэзия садов. К семантике садово-парковых стилей. Сад как текст. - М.: Просвещение, 1998. - 450 с.

9. Боговая И. О., Фурсова Л.М. Ландшафтное искусство. - М.: Агропромиздат, 1988. $-233 \mathrm{c}$.

10. Колесникова Е. Г. Декоративные травы. - М.: Кладезь-Букс, 2006. - 96 с

11. Мигаль С. П. Методологічні концепції ландшафтного дизайну та їх еволюція в сучасних умовах // Вісник НУ «ЛП», 2013. - № 757. - С. 355-367.

12. Фітостіни [Електронний ресурc] - ROYAL DÉCOR. - Режим доступу до pecypcy: https://royaldecor.com.ua/our_products/fitostini/

13. Зелений тренд: чому озеленення торгових центрів стає популярним [Електронний ресурс] - RAU. - Режим доступу до ресурсу: https://rau.ua/novyni/novinipartneriv/zelenyj-trend-shen/

14. MFO-Park [Електронний pecypc] - Recreation, Zürich, Switzerland. - Режим доступу до ресурсу: https://www.zuerich.com/en/visit/attractions/mfo-park

UDC 72.012

doi: $10.31650 / 2519-4208-2020-20-258-263$

\title{
ARCHITECTURAL AND DESIGN SCENOGRAPHY MODEL
}

Turikova E. candidate of pedagogical Sciences, department of design of architectural environment.

Odessa State Academy of Civil Engineering and Architecture. Ukraine +38(063) 6145345

Titinov V. Institute Teacher of Department of Architectural Environment Design Odessa State Academy of building and architecture. Ukraine +38(067) 9841957

Pogorolev O. Institute Teacher of Department of Architectural Environment Design Odessa State Academy of Civil Engineering and Architecture. Ukraine $+38(097) 5344206$

Abstract: The paper focuses on the development and description of an environmental scenography model. The presented material seeks to characterize the concepts included in the complex of "architectural and design scenography", to identify and summarize the structural-component composition of the architectural and design scenography. The paper is based on the synthesis of the conceptual framework of stage scenography and environmental approach in the design of the architectural environment. Based on the specific experience of architectural theorists and practitioners who experimented in stage scenography, organization of production processes outside 
the theaters, the parallels were drawn between the theory and practice of environmental and stage scenography.

In view of the foregoing, the nomenclature of environmental scenography has been clarified and expanded. It was found that the architectural and design scenography is implemented in the formation of visual impressions as part of various scenarios of user and environment interaction. At the same time, the environment and its components are "mobile substance", which is perceived in dynamics, in the course of its interaction with users, in spatial amplifications, metamorphoses, overlapping of "pictures", etc. With a scenographic approach to the design of the architectural environment, the organization of various connections comes to the fore for a variety of visual contact conditions between the environment and the user.

The paper describes the concept of "architectural and design scenography" (ADS), outlines the scope of its application in the architectural design, emphasizes the priority of visual perception, provides examples of the mutual enrichment of the scenographic and architectural practice. The definition of ADS as a type of artistic design of the architectural environment aimed at creation of its graphical-plastic image, and the definition of the visual and aesthetic significance of the environment image are clarified. The main functions of the environmental scenography are listed: character, acting functions and designation of the scene.

The structural-component composition of the ADS includes 3 compositional systems, 3 architectonic levels, 4 content-related levels, means of expression, composite components, and stages.

Key words:The proposed environmental scenography model is presented in the form of a table.

\section{МОДЕЛЬ АРХИТЕКТУРНО-ДИЗАЙНЕРСКОЙ СЦЕНОГРАФИИ}

Тюрикова Е. Н., канд. педагогических наук, доц. каф. ДАС

Погорелов О. А., старший преподаватель каф. ДАС

Титинов В. В., ассистент каф. ДАС

Одесская государственная академия строительства и архитектуры

Аннотация: В статье исследуется сценографический подход в архитектурном дизайне. На основе экстраполирования теоретических и практических наработок в области театрального искусства расширен понятийный аппарат средовой сценографии, выделены её компонентный состав, материал, выразительные средства; определены функции и принципы организации (сценарного ряда) средовых впечатлений; композиционные, архитектонические и содержательные уровни; выявлен средовой модуль; разработана модель средовой сценографии (МСС).

Ключевые слова: архитектурная среда, сценографический подход, архитектурнодизайнерская (средовая) сценография, модель средовой сценографии.

\section{МОДЕЛЬ АРХІТЕКТУРНО-ДИЗАЙНЕРСЬКОЇ СЦЕНОГРАФІЇ}

Тюрікова О. М. канд. педагогічних наук, доц. каф. ДАС

Погорелов О. А. старший викладач каф. ДАС

Титинов В. В. асистент каф. ДАС

Одеська державна академія будівництва та архітектури

Анотація: У статті досліджується сценографічний підхід в архітектурному дизайні. На основі екстраполевання теоретичних і практичних напрацювань в галузі театрального мистецтва розширено понятійний апарат середовищної сценографії, виділені іiі компонентний склад, матеріал, виражальні засоби; визначені функції та принципи організації (сценарного ряду) середовищних вражень; композиційні, архітектонічні та 
змістовні рівні; виявлено середовищний модуль; розроблена модель середовищної сценографії (МСC).

Ключові слова: архітектурне середовище, сценографічний підхід, архітектурнодизайнерська (середовищна) сценографія, модель середовищної сценографії.

The relevance is caused by the need to make changes to the historically formed environmental complexes while maintaining their integrity and recognition, to develop the strategies and tactics of constant updates in the architectural environment.

The problem of the study is the architectural and design scenography of the architectural environment.

The exploration degree of the problem.

Various aspects of the scenographic approach in architectural and design projecting were investigated by V. Glazychev, A. Gutnov, A. Ikonnikov, G. Zabelshanskiy, I. Lezhava, A. Rappaport, I. Rozenson, S. Stepanova, V. Shimko and others.

Interpretation of the urban environment as an open-air performance is typical for authors such as A. Ikonnikov, N. Morgun, L. Reznitskaya, I. Rozenson, A. Skopintsev and others.

Nevertheless, the contradictions between the degree of scientific elaboration of the scenographic approach in the architectural environment design and project practice force designers to create their own arsenal of methods and tools that ensure the expressiveness of each specific environmental situation. In this paper, we made an attempt to "harmonize" the methods of architectural design and theatrical production, and on this basis to develop a structural and functional model of architectural and design scenography.

The study object is architectural and design scenography.

The subject of the study is a model of architectural and design scenography.

The objective is to develop a model of architectural and design scenography.

Tasks:

- to characterize the concepts of "architectural and design scenography" (hereinafter referred to as ADS);

- to identify and summarize the structural-component composition of the ADS;

- to develop and describe an environmental scenography model.

A large number of architectural theorists and practitioners experimented in stage scenography, organization of production processes outside the theaters, which makes it possible to draw parallels between the theory and practice of environmental and stage scenography.

The scenographic experience of famous architects demonstrates the uniquely designed approaches to deal with the environment [3, p. 536]:

- the innovative approach of Edward Gordon Craig, in whose compositions the stage space acted as an additional actor;

- "deconstructivism" by Frank Gehry, with his conceptual solutions in the form of "moving still-lifes on stage" [4];

- the concept of stage minimalism, the idea of "dancing in the void" by John Pawson, which implies the movement of actors "from nowhere to nowhere";

- the author's style of "cable-stayed bridges" by Santiago Calatrava, expressed in the use of non-functional open work structures made of nylon stretched on an aluminum frame";

- psychedelic art maneuvers by Hiroshi Koike, which symbolized the "decay" in the relationships of the characters by means of "dismantling" decorations;

- the traditions of the Latvian architectural school, which interprets scenography as a mean for creation of the various spatial situations, formation of the stage structure so that it enables the use of a variety of scenarios;

- a fan of approaches to scenography from the representatives of the Russian architectural school: the realism by F. Shekhtel [6]; the transition from picturesque to constructivism, cubism 
and stylization of the real architecture forms by A. Vesnin [7]; the resort to the cultural traditions of different countries, to eclecticism of S. Barkhin [9], his desire to combine the heterogeneous, incompatible and different-style; the use of "comic strip" techniques, grotesque lines of sight and perspectives, the deliberate lack of planning, the implementation of the "technogenic ruins" idea that change their nature, in the works by G. Tsypin [8], etc.

In architectural design, the simultaneous method of material designing of medieval mysteries (M. Frenkel), the tendency to turn to the "conditional theater" (V. Meyerhold) are actualized.

The theater science advances of V. Ivanov, M. Frenkel, V. Meyerhold, Shepovalov and others [2] make it possible to identify analogies and expand the nomenclature in the field of environmental design. Today, along with such terms as "chronotope", "visual field", "total image of the environment", "spatiotemporal framework", "cultural-visual layers and pictures", "experienced" time and space, etc. [1-3], the concepts of "markers", "mise-en-scene", "thematic zones", "visual field", "locus", "patterns" [1], etc. are introduced.

The architectural and design scenography is implemented in the formation of visual impressions as part of various scenarios of user and environment interaction. At the same time, the environment and its components are "mobile substance", which is perceived in dynamics, in the course of its interaction with users, in spatial amplifications, metamorphoses, overlapping of "pictures", etc. With a scenographic approach to the design of the architectural environment, the organization of functional, semantic, visual, "hereditary" and other connections for a variety of conditions of visual contact between the environment and the consumer comes to the fore.

The priority of the environment "spectacularity" quality is most clearly manifested in the projects of the decoration environment: the design of festivals, exhibition complexes, temporary events [4], the organization of an interactive environment where the audience is involved in the process by functioning with various "environmental actors" [2, p. 221-441]. By analogy with theatrical events, the principle of creation of a space "around rituals" that determine the atmosphere and mood [4]; the desire to build a backbone chain "introduction - action - apotheosis - denouement - epilogue - a new introduction" is actualized in environmental design.

An analysis of theoretical advances in the field of architecture and design [8] made it possible to make some generalizations.

Architectural scenography is considered [8] as:

- project strategy for the reconstruction of the historical environment;

- factor of environment image strengthening;

- mechanism for the formation of environmental dialogues;

- means of achieving interactivity, etc.

Scenography methods are applied for [8]:

- mass distribution in space;

- detailing of the space masses in the dynamics of motion and interaction;

- identification of the masses in their light-color relationships.

The scenographic solution of the architectural environment is contextual and dialogical.

The environment module is a consumer who defines and sets its scenography.

The scenographic model is implemented in four content-related levels - the layers (markers - mise-en-scene - thematic zones - integrated scenario) [4].

Table 1 presents the structural-functional model of environmental scenography, where a hierarchy of its categories, component composition, objective, means of its achievement and the expected result are built. Based on this model, an algorithm or model of professional activity of an architect-designer in the current environment is built. 
ISSN 2519-4208. ПРОБЛЕМЫ ТЕОРИИ И ИСТОРИИ АРХИТЕКТУРЫ УКРАИНЫ. 2020. № 20

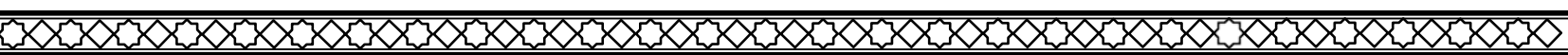

Table 1. Structural-functional model of environmental scenography

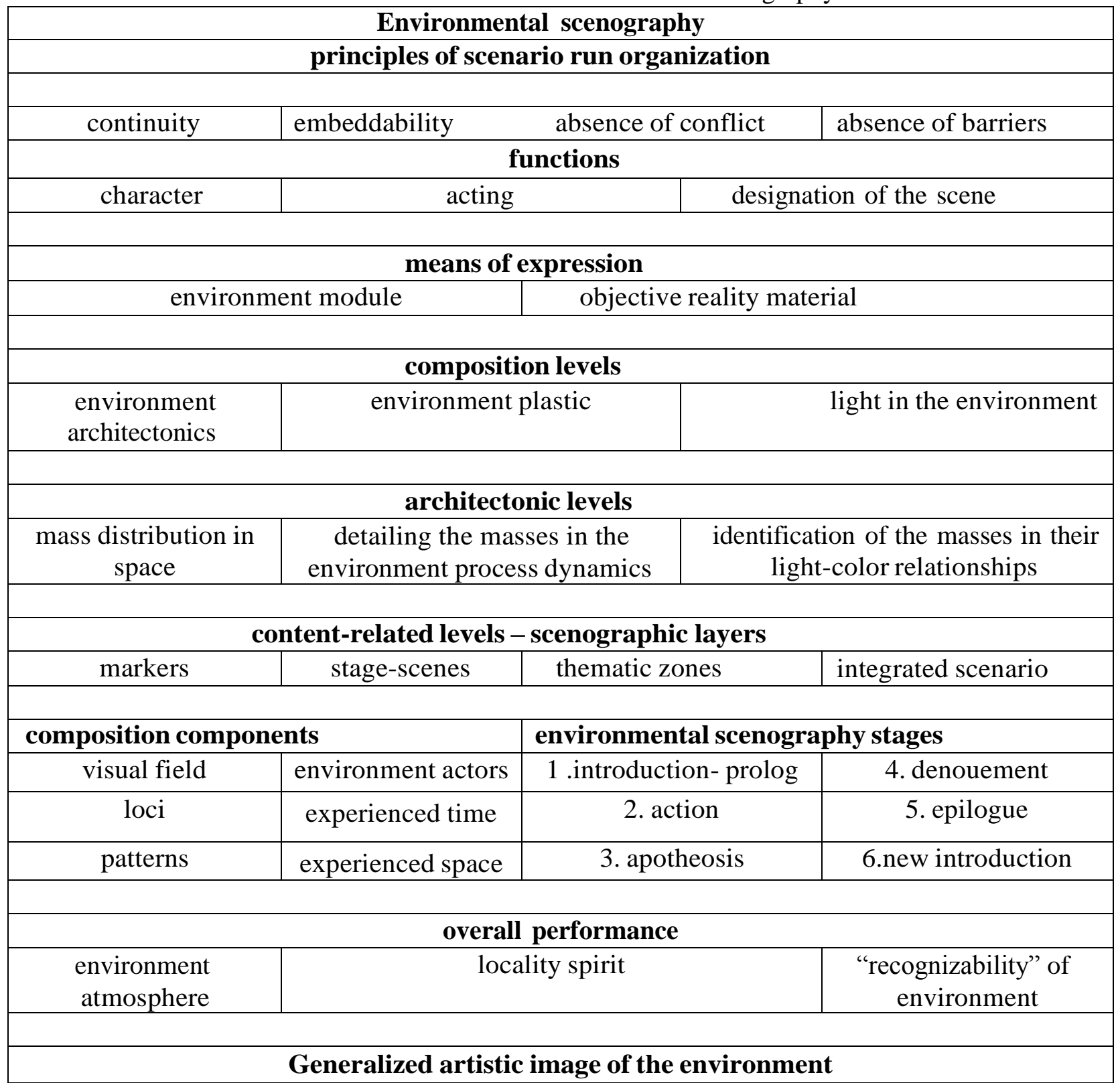

\section{Conclusions:}

Thus, the paper characterizes the concept of "architectural and design scenography" (ADS), outlines the scope of its application in the architectural design, emphasizes the priority of visual perception, provides examples of the mutual enrichment of the scenographic and architectural practice. The definition of ADS as a type of artistic design of the architectural environment aimed at creation of its graphical-plastic image, and the definition of the visual and aesthetic significance of the environment image are clarified. The main functions of the environmental scenography are listed: character, acting functions and designation of the scene.

The structural-component composition of the ADS includes 3 compositional systems, 3 architectonic levels, 4 content-related levels, means of expression, composite components, and stages.

The environmental scenography model is proposed.

Further studies may be devoted to the implementation and specification of the proposed model in a specific context from architectural and design practice. 


\section{LITERATURE}

1. Glazychev V. Essays on Design Theory and Practice in the West [Text] / V. Glazychev - M.: Art, 1970. -108 p.

2. Degtyanikova N. Heuristic methods in the study of the composition of works of art: avtoref. thesis. ... Ph.D. in History of Arts / N. Degtyanikova - Jour., 2004. - 20 p.

3. Ikonnikov A. Space and form in architecture and urban planning [Text] / A. Ikonnikov - M.: «КомКniga», 2006. - 176 p.

4. Koveshnikova N. Design. History and Theory [Text] / N. Koveshnikova N. - M.: Omega -L, 2009. - 224 p. - ISBN: 978-5-370-01250-1.

5. Stepanova S. The aspect of visual perception in the architectural space of the city as a contribution to the development of cross-border cooperation in the Asia-Pacific region: materials of the international scientific-practical conference dedicated to the 65th anniversary of the Khabarovsk-Krai one-day formation "Development of interactions in the legal and economic space of the Asia-Pacific countries: Formal and informal aspects". - Khabarovsk: RICHGAEP, 2003. 323 p. - C. 91-93.

6 Stepanova S. Visual image of the modern city environment (statement of the problem): materials of the scientific conference of the faculty and young scientists dedicated to the 70th anniversary of the Moscow Architectural Institute, abstracts of papers "Architectural Science and Education". $286 \mathrm{p}$.

7. Kudin P. Psychology of Perception and Poster Art / P. Kudin, B. Lomov, A. Mytkin. -M.: Post, 1987. -208 p.

8. Sheluh S. Artistic image and composition in the design of furniture of the period of the XVIII early XXI centuries: aftoref. thesis. ... Ph.D. in History of Arts / S. Sheluh. . - M., 2005. $-26 \mathrm{p}$.

9. Shymko V. Architectural and design design. Fundamentals of the theory (environmental approach) / V. Shymko - M.: Arhitecture C, 2009. - 219 p.

10. Shymko V Architectural and design design of the urban environment / V. Shymko- M.:

Arhitecture C, 2006. - 127 p.

11. The design of the future century. [Electronic resource] - http://www.ielastic.ru/

12. Morhun N. Architectural scenography of the urban environment as a design strategy for the reconstruction of the historic city center and a factor in strengthening its tourist image / N. Morhun, L. Reznyckaya, A. Skopyncev - article UAO, Rostov-na-Dony, Russia.

UDC 711.04 doi: $10.31650 / 2519-4208-2020-20-263-271$

\section{ARCHITECTURAL LIGHTING OF THE INTERIOR SPACES OF RESIDENTIAL AND PUBLIC BUILDINGS (LIGHT COMFORT)}

Vasylenko O., Doctor of Architecture, Professor, Department of architect design e-mail: abvasilenko10@gmail.com,ORCID: 0000-0002-8261-3104

Mykhailenko O., assistant of the Department Design of Architectural Environment

Shmarev I., Master of Architecture and Urban Planning, Department of architect design

Tanirverdiyev A., Master of Architecture and Urban Planning, Department of architect design Odessa State Academy of Civil Engineering and Architecture, Ukraine

tel. 096-770-15-68

Abstract: The paper identified the main aspects of the natural lighting of interior spaces of residential and public buildings, affecting the light forms of education, the quality of light, visual comfort, visual discomfort, uneven illumination, and so on. 